\title{
PENGARUH TINGKAT PENDIDIKAN ORANG TUA TERHADAP PRESTASI BELAJAR ANAK SEKOLAH DASAR
}

\author{
Jati Rahmadana, Ichsan \\ Pendidikan Guru Madrasah Ibtidaiyah, Fakultas Tarbiyah Dan Ilmu Keguruan, \\ UIN Sunan Kalijaga Yogyakarta \\ e-mail: jatirahmadana@gmail.com, Ichsandjalal@gmail.com
}

\begin{abstract}
This study aims to examine the effect of parental education level on learning achievement of elementary school students. This type of research is Ex Post facto research, using a qualitative descriptive approach. The data analysis technique used in this research is meta analysis. The results of this study indicate that the education level of parents has a clear influence on the child's learning process which is seen based on their learning achievement in school. With this level of confidence, it will significantly affect the academic ability of children. Through this paper, so that it can be an afterthought and material for introspection for parents, not only do parents demand that their children be able and achieve good learning achievements, but parents also have a responsibility to continue learning, because the higher the level of education or knowledge is owned by parents, will encourage good learning achievement for a child.
\end{abstract}

Key Word : Parents' Education, Learning Achievement

\begin{abstract}
ABSTRAK
Penelitian ini bertujuan untuk mengkaji pengaruh tingkat pendidikan orang tua terhadap prestasi belajar peserta didik Sekolah Dasar. Jenis penelitian ini adalah penelitian Ex Post Facto, dengan menggunakan pendekatan deskriptif kualitatif. Teknik analisis data yang digunakan dalam penelitian ini adalah meta analisis. Hasil penelitian ini menunjukkan bahwa tingkat pendidikan orang tua memberikan pengaruh yang jelas terhadap proses belajar anak yang dilihat berdasarkan prestasi belajar mereka di sekolah. Dengan tingkat keyakinan tersebut maka akan berpengaruh secara signifikan terhadap kemampuan akademis anak-anak. Melalui tulisan ini agar dapat menjadi renungan dan bahan instropeksi bagi para orang tua, jangan hanya orang tua menuntut anak untuk bisa dan meraih prestasi belajar yang baik, akan tetapi para orang tua juga memiliki tanggung jawab untuk terus belajar, karena semakin tinggi tingkat pendidikan atau ilmu yang dimiliki oleh orang tua, akan mendorong prestasi belajar yang baik bagi seorang anak.
\end{abstract}

Kata Kunci: Pendidikan Orang Tua, Prestasi Belajar

\section{PENDAHULUAN}

Keberhasilan dalam pendidikan dipengaruhi oleh berbagai macam faktor. Faktor-faktor yang mempengaruhi keberhasilan proses pendidikan yaitu faktor lingkungan keluarga, lingkungan sekolah, dan lingkungan masyarakat. Dari beberapa 
faktor tersebut, salah satu kunci dalam pendidikan ialah peranan orang tua dalam lingkungan keluarga siswa untuk sebagai pendorong yang memberi semangat, penasehat serta teman menjadi contoh anaknya selain sebagai orang yang mencintai, yang memberi kasih sayang dan tempat bertanya anaknya. Pada pasal 7 ayat (2) undangundang nomor 20 tentang sistem pendidikan nasional, disebutkan bahwa "orang tua dari anak usia wajib belajar, wajib memberikan pendidikan dasar kepada lingkungan keluarga ini sebagai tempat pertama pertumbuhan dan perkembangan anak-anaknya". Orang tua mempunyai tanggung jawab penuh atas anak-anaknya. Peran orang tua menyediakan materi dan membantu anaknya saat-saat mengalami kesulitan dalam proses belajar. ${ }^{1}$

Menurut Anang Santoso dalam Riana, "keluarga memiliki kedudukan yang sangat strategis dalam mengembangkan manusia Indonesia masa depan yang modern dengan tuntunan zaman. Sejak dini orang tua dapat menanamkan nilai-nilai modernitas yang akhirnya dapat dikembangkan sendiri oleh anak didik di dalam perjalanan hidupnya. Lingkungan keluarga (orang tua) merupakan pusat pendidikan pertama dan utama bagi seorang anak. Keluarga merupakan proses penentu dalam keberhasilan belajar. Orang tua sebagai pendidik pertama karena orang tualah yang pertama mendidik anaknya sejak dan sebagai pendidik utama karena pendidikan yang diberikan orang tua merupakan dasar dan sangat menentukan perkembangan anak selanjutnya. ${ }^{2}$

Agar siswa dapat memahami dan memiliki minat terhadap mata pelajaran orang tua perlu memberikan perhatian kepada anak sehingga memahami apa yang dibutuhkan anak agar dapat meningkatkan prestasi belajar. Dalam kenyataannya, masih banyak orang tua beranggapan bahwa masalah pendidikan adalah urusan guru, maka lenyaplah tanggung jawab orang tua dalam memerhatikan pendidikan anaknya. Selain perhatian orang tua, latar belakang pendidikan orang tua juga dapat memberikan pengaruh terhadap minat belajar anak, yang pada akhirnya akan berpengaruh terhadap prestasi belajar anak. Persepsi siswa tentang pendidikan orang tua akan memengaruhi persepsi

${ }^{1}$ Sri Reskia dkk, Pengaruh Tingkat Pendidikan Orang Tua Terhadap Prestasi Belajar Siswa Di Sdn Inpres 1 Birobuli, Elementary School of Education E-Journal, Media Publikasi Ilmiah Prodi PGSD Vol 2, Nomor 2, Juni 2014, hlm. 82-83

${ }^{2}$ Ibid. 
mereka terhadap pentingnya pendidikan itu sendiri sehingga akan memengaruhi prestasi belajar mereka. ${ }^{3}$

Menurut Muhammad Shoehib dalam Riana, agar keluarga dapat memainkan perannya sebagai pendidik, ia perlu dibekali dengan pengetahuan dan keterampilan. Keterkaitan orang tua dalam hal ini sangat penting, apalagi kalau dilihat dalam pendidikan. Salah satu contohnya, apabila ada pekerjaan rumah yang tidak bisa dijawab, orang tua sebaiknya membantu dan membimbing anaknya. Sehingga peran orang tua tidak hanya sekedar memberikan uang jajan atau menyekolahkan, tetapi juga ikut berperan dalam proses pendidikan anaknya. ${ }^{4}$

Peserta didik yang berada di dalam kelas berasal dari latar belakang yang berbeda, baik itu berdasarkan daerah, bahasa, jenis pekerjaan serta tingkat pendidikan orang tua. Tujuan penulisan artikel ini adalah untuk melihat apakah terdapat pengaruh yang signifikan antara tingkat pendidikan orang tua dengan prestasi belajar peserta didik kelas Sekolah Dasar.

\section{METODE PENELITIAN}

Penelitian yang penulis lakukan merupakan penelitian Ex Post Facto. Penelitian Ex Post Facto merupakan penelitian yang bertujuan menemukan penyebab yang memungkinkan perubahan perilaku, gejala atau fenomena yang disebabkan oleh suatu peristiwa, perilaku atau hal-hal yang menyebabkan perubahan pada variabel bebas yang secara keseluruhan sudah terjadi. Definisi Ex Post Facto adalah sesudah fakta, yaitu penelitian yang dilakukan setelah suatu kejadian itu terjadi. Penelitian ex post facto bertujuan menemukan penyebab yang memungkinkan perubahan perilaku, gejala atau fenomena yang disebabkan oleh suatu peristiwa, perilaku atau hal-hal yang menyebabkan perubahan pada variabel bebas secara keseluruhan sudah terjadi. ${ }^{5}$

Pendekatan dalam penelitian ini adalah deskriptif kualitatif. Penelitian kualitatif merupakan penelitian yang bermaksud untuk memahami fenomena tentang apa yang dialami subjek penelitian secara holistik dengan cara mendeskripsikan dalam bentuk

${ }^{3}$ Noor Komari Pratiwi, Pengaruh Tingkat Pendidikan, Perhatian Orang Tua, Dan Minat Belajar Siswa Terhadap Prestasi Belajar Bahasa Indonesia Siswa Smk Kesehatan Di Kota Tangerang, Jurnal Pujangga Volume 1, Nomor 2, Desember 2015. hlm.78

${ }^{4}$ Sri Reskia, ..... hlm. 83

${ }^{5}$ Widiarto, Penelitian ex post facto, Fakultas Teknik Universitas Negeri Yogyakarta, 2013, hlm. 2-3 
kata-kata pada konteks ilmiah. Pendekatan ini digunakan untuk menghasilkan data deskripsi berupa kata-kata tertulis maupun lisan dari orang-orang dan perilaku yang diamati. Pendekatan ini dilakukan guna mendapatkan data mendalam dengan teknik observasi, wawancara dan dokumentasi. ${ }^{6}$

Teknik analisis data yang digunakan dalam penelitian ini adalah Meta Analisis. Meta Analisis adalah informasi terstruktur yang mendeskripsikan, menjelaskan, menemukan, atau setidaknya menjadi suatu informasi yang mudah untuk ditemukan kembali, digunakan, atau dikelola. ${ }^{7}$ Penelitian meta analisis ini merupakan penelitian yang menggunakan data sekunder berupa data-data dari hasil penelitian sebelumnya. Dengan demikian penelitian ini dapat disebut sebagai penelitian yang bersifat ex post facto yang berbentuk survey dan analisis kepustakaan terhadap penelitian-penelitian yang telah dilakukan.

Meta analisis pada hakekatnya merupakan sintesis sebuah topik yang diambil dari beberapa laporan penelitian. Berdasarkan sintesis tersebut ditarik sebuah kesimpulan mengenai topik yang diteliti. Penelitian ini menggunakan hasil-hasil penelitian yang sejenis sebagai data dasar dalam melakukan kajian dan kesimpulan Effect size, yakni perbedaan kejadian efek antara kelompok eksperimental dan kelompok kontrol dalam meta-analisis merupakan gabungan effect size masing-masing studi yang dilakukan dengan teknik statistika tertentu. Karena pada umumnya pembuat meta-analisis tidak memiliki data dasar penelitian, maka praktis dimensi effect size yang digabungkan dalam meta-analisis sama dengan yang dilaporkan dalam artikel yang digabungkan. ${ }^{8}$

\section{HASIL PENELITIAN DAN PEMBAHASAN}

\section{Prestasi Belajar}

Hasil belajar merupakan perubahan perilaku, baik peningkatan pengetahuan, perbaikan sikap, maupun peningkatan keterampilan yang dialami siswa setelah menyelesaikan kegiatan pembelajaran. Hasil belajar yang sering

${ }^{6}$ Sugiyono, Metode Penelitian Kuantitatif, Kualitatif dan R\&D, ( Bandung: Alfabeta, 2018 ), hlm. 24

7 Maulida Anggraina Saputri, Penerapan Model Pembelajaran Problem Based Learning Untuk Meningkatkan Kemampuan Berfikir Kritis Siswa Kelas V Sekolah Dasar, Jurnal pendidikan dan konseling, Vol. 1 No. 2, 2020, hlm.111

${ }^{8}$ Sokhibul Ansor, Studi Meta Analisis Strategi Dan Pemanfaatan Jurnal Elektronik (E - Journals) Untuk Mahasiswa Lulusan Universitas Negeri Malang Dalam Upaya Publikasi Ilmiah Bereputasi Internasional, Record And Library Journal, Vol 3, No 1 2017, hlm. 69 
disebut juga prestasi belajar, tidak dapat dipisahkan dari aktivitas belajar, karena belajar merupakan suatu proses, sedangkan prestasi belajar adalah hasil dari proses pembelajaran tersebut. Hasil belajar adalah kemampuan yang diperoleh anak melalui kegiatan belajar. Dalam kegiatan belajar yang terprogram dan terkontrol yang disebut kegiatan pembelajaran, tujuan belajar telah ditetapkan terlebih dahulu oleh guru, anak yang berhasil dalam belajar adalah anak yang berhasil mencapai tujuan-tujuan pembelajaran. Untuk mendapatkan suatu prestasi tidaklah semudah yang dibayangkan, karena memerlukan perjuangan dan pengorbanan berbagai tantangan yang harus dihadapi. ${ }^{9}$

Winkel menjelaskan bahwa proses belajar yang dialami oleh siswa belajar menghasilkan perubahan-perubahan dalam bidang pengetahuan dan pemahaman, dalam bidang nilai, sikap, dan keterampilan. Adanya perubahan tersebut tampak dalam prestasi belajar yang dihasilkan oleh siswa terhadap pertanyaan, persoalan, atau tugas yang diberikan oleh guru. Melalui prestasi belajar siswa dapat mengetahui kemajuan-kemajuan yang telah dicapai dalam belajar. Marsun dan Martaniah dalam Hidayat berpendapat bahwa prestasi belajar merupakan hasil kegiatan belajar, yaitu sejauh mana peserta didik menguasai bahan pelajaran yang diajarkan, yang diikuti oleh munculnya perasaan puas bahwa ia telah melakukan sesuatu dengan baik. Hal ini berarti prestasi belajar hanya bisa diketahui jika telah dilakukan penilaian terhadap hasil belajar siswa. ${ }^{10}$

Menurut Poerwodarminto dalam Hidayat, yang dimaksud dengan prestasi adalah hasil yang telah dicapai, dilakukan atau dikerjakan oleh seseorang. Sedangkan prestasi belajar itu sendiri diartikan sebagai prestasi yang dicapai oleh seorang siswa pada jangka waktu tertentu dan dicatat dalam buku rapor sekolah. Prestasi belajar merupakan hasil yang diperoleh seseorang dalam belajar sesuai kapasitas (kemampuan, kecakapan, dan kesanggupan) yang dimilikinya. Kapasitas yang terdapat dalam individu antara lain intelegensi, bakat, minat, dan motivasi yang semuanya itu memengaruhi pencapaian belajar yang maksimal. Prestasi belajar adalah kecakapan nyata atau aktual yang menunjukan adanya aspek kecakapan yang segera didemonstrasikan dan

${ }^{9}$ Noor Komari Pratiwi, ..... hlm. 80-81

${ }^{10} \mathrm{Ibid}$. 
diujikan karena merupakan hasil usaha belajar yang dicapai di sekolah baik berupa pengetahuan, sikap, atau keterampilan yang dimanifestasikan dalam bentuk nilai. ${ }^{11}$

Sobur Menjelaskan, prestasi akademik merupakan perubahan dalam hal kecakapan tingkah laku, ataupun kemampuan yang dapat bertambah selama beberapa waktu dan tidak disebabkan proses pertumbuhan, tetapi adanya situasi belajar. Perwujudan bentuk proses hasil belajar tersebut dapat berupa pemecahan lisan maupun tulisan, dan keterampilan serta pemecahan masalah langsung dapat diukur atau dinilai dengan tes yang terstandar. ${ }^{12}$

Berdasarkan uraian dari beberapa pendapat tersebut, maka dapat dikatakan bahwa prestasi akademik adalah hasil atau pencapaian keberhasilan yang diperoleh karena usaha belajar atau sebagai hasil akhir dari aktivitas belajar.

\section{Pengaruh Pendidikan Orang Tua Terhadap Prestasi Belajar Siswa.}

Pendidikan sangatlah penting peranannya dalam kehidupan bermasyarakat. Dengan memiliki pendidikan yang cukup maka seseorang akan mengetahui mana yang baik dan mana yang dapat menjadikan seseorang menjadi berguna baik untuk dirinya sendiri maupun untuk orang lain yang membutuhkannya. Menurut Undang-undang Republik Indonesia No. 20 tahun 2003 tentang sistem Pendidikan Nasional Pasal 1 ayat 1 yaitu "pendidikan adalah usaha sadar dan terencana untuk mewujudkan suasana belajar dan proses pembelajaran agar peserta didik secara aktif mengembangkan potensi dirinya untuk memiliki kekuatan spiritual keagamaan, pengendalian diri, kepribadian, kecerdasan, akhlak mulia, serta ketrampilan yang diperlukan dirinya, masyarakat bangsa dan negara".13

Ali Saifullah menambahkan pengertian pendidikan yaitu usaha manusia untuk membina kepribadiannya sesuai dengan nilainilai di dalam masyarakat dan kebutuhannya. Lester D. Crow berpendapat, pendidikan adalah proses individualisasi dan sosialisasi yang lebih lanjut dapat dinyatakan bahwa

\footnotetext{
${ }^{11} \mathrm{Ibid}$.

12 Henry Eryanto, Darma Rika, 2013, Pengaruh Modal Budaya, Tingkat Pendidikan Orang Tua Dan Tingkat Pendapatan Orang Tua Terhadap Prestasi Akademik Pada Mahasiswa Fakultas Ekonomi Universitas Negeri Jakarta, Jurnal Pendidikan Ekonomi Dan Bisnis Vol.1 No. 1. hlm. 42

${ }^{13}$ Ibid. hlm, 48
} 
kemajuan yang diperoleh seseorang berarti juga kemajuan bagi masyarakat dimana ia bertempat tinggal. ${ }^{14}$

Dari berbagai pendapat para ahli diatas maka dapat dikatakan bahwa pendidikan merupakan sebuah proses untuk mengembangkan pikiran, watak, keterampilan yang diperoleh melalui pembelajaran dalam rangka mencapai tujuan.

Tingkat pendidikan adalah tahapan pendidikan yang ditetapkan berdasarkan tingkat perkembangan peserta didik, tujuanyang akan dicapai dan kemauan yang dikembangkan. Tingkat pendidikan berpengaruh terhadap perubahan sikap dan perilaku hidup sehat. Tingkat pendidikan yang lebih tinggi akan memudahkan sesorang atau masyarakat untuk menyerap informasi dan mengimplementasikannya dalam perilaku dan gaya hidup sehari-hari. Pendidikan formal membentuk nilai bagi seseorang terutama dalam menerima hal baru. Tingkat pendidikan orang tua adalah tingkat pendidikan formal berdasarkan ijazah yang diperoleh oleh orang tua, dalam penelitian ini adalah ayah dan ibu kandung dari siswa yang dijadikan sampel dalam penelitian ini. Diharapkan dengan tingkat pendidikan yang cukup dapat membuat anak mencapai prestasi belajar yang optimal. ${ }^{15}$

Pengaruh tingkat pendidikan orang tua pada prestasi terbaik siswa mungkin direpresentasikan sebagai hubungan yang dimediasi oleh interaksi antara proses dan variabel status.Tingkat pendidikan yang dimaksud dalam penelitian ini adalah pendidikan yang berstruktur dan berjenjang dengan periode tertentu serta memiliki program dan tujuan yang disesuaikan dengan jenjang yang diikuti dalam mendidik. Orang tua bertanggung jawab terhadap pendidikan anak-anaknya untuk menerima tanggung jawab yang penting ini, maka harus mempersiapkan diri sebelum dan sesudah menikah, tanggung jawab orang tua tidaklah terbatas dalam memberi makan, minum, pakaian, dan perlindungan saja, akan tetapi ia juga terikat dalam tugas mengembangkan pikiran dan upaya untuk melatih anaknya secar fisik, spirit, moral, dan sosial. Orang tua adalah figur dalam proses pembentukan kepribadian anak, sehinggan diharapkan akan

${ }^{14}$ Ibid.

${ }^{15}$ Noor Komari Pratiwi, .... hlm. 85 
memberi arah, memantau, mengawasi, dan membimbing perkembangan anaknya kearah yang lebih baik. ${ }^{16}$

Berdasarkan hal-hal yang diutarakan di atas dapat diperoleh pengertian bahwa orang tua tidak hanya cukup memberi makan inum, dan pakaian kepada anakanaknya tetapi harus berusaha agar anaknya menjadi baik, pandai, bahagia, dan berguna bagi hidup dan masyarakat.

Menurut zahara, keberhasilan pendidikan seorang anak terutama yang menyangkutkan pencapaian prestasi belajar yang baik dipengaruhi oleh beberapa faktor salah satunya adalah bagaimana cara orang tua mengarahkan cara belajar anaknya. Jadi tingkat pendidikan seseorang akan berpengaruh dengan perkembangan potensi yang dimilikinya termasuk potensi emosional, pengetahuan, sikap, dan keterampilan. Dengan kematangan emosional, pengeahuan, sikapyang dimiliki oleh orang tua sedikit banyaknya akan memberikan kontribusi bagi anakanaknya. Orang tua dengan tingkat pendidikan yang lebih tinggi juga memungkinkan untuk lebih percaya diri pada kemampuan mereka dalam membantu anak-anak mereka belajar. Dengan tingkat keyakinan tersebut maka diperkirakan akan berpengaruh secara signifikan terhadap kemampuan akademis anak-anak. ${ }^{17}$

Munandar menjelaskan, pada umumnya tampak bahwa makin tinggi tingkat pendidikan orang tua, makin baik prestasi anak. Jika membandingkan prestasi anak yang ayahnya berpendidikan SLTA atau lebih tinggi dengan prestasi anak yang pendidikan ayahnya lebih rendah dari SLTA, maka pada tingkat SD tampak perbedaan yang nyata dalam skor kreativitas, inteligensi, daya ingat, dan prestasi sekolah; tetapi pada tingkat SMP perbedaannya hanya bermakna dalam prestasi sekolah. Yang menarik adalah bahwa pendidikan ibu lebih jelas dan positif hubungannya dengan prestasi anak, daripada pendidikan ayah. Di SD maupun SMP kelompok anak yang pendidikan ibunya SLTA atau lebih skornya nyata lebih tinggi pada kreativitas, inteligensi, dan prestasi sekolah, daripada kelompok anak yang pendidikan ibunya lebih rendah dari SLTA. ${ }^{18}$

\footnotetext{
${ }^{16}$ Sri Reskia, 86

${ }^{17}$ Ibid.

${ }^{18}$ Noor Komari Pratiwi,...hlm. 79
} 
Ngalim Purwanto juga menegaskan bahwa orang tua adalah pendidik sejati, pendidik karena kodratnya. Karena memang sudah secara kodrat orang tua mendidik anak, maka yang diharapkan pasti yang terbaik untuk anaknya. Abu Ahmadi menyatakan bahwa tingkat pendidikan orang tua adalah pendidikan formal tertinggi yang berhasil ditempuh oleh orang tua. Sedangkan menurut Dalyono, faktor orang tua sangat besar pengaruhnya terhadap keberhasilan anak dalam belajar. Tinggi rendahnya pendidikan orang tua, besar kecilnya penghasilan, cukup atau kurang perhatian dan bimbingan orang tua, rukun atau tidaknya kedua orang tua, akrab atau tidaknya hubungan orang tua dengan anakanak, tenang atau tidaknya situasi dalam rumah, semuanya mempengaruhi keberhasilan belajar. ${ }^{19}$

Berdasarkan analisis yang peneliti lakukan dari artikel yang menjadi bahan rujukan, dapat peneliti ambil sebuah kesimpulan bahwasanya tingkat pendidikan orang tua memberikan pengaruh yang besar terhadap prestasi belajar seorang anak. Orang tua dengan tingkat pendidikan yang lebih tinggi juga memungkinkan untuk lebih percaya diri pada kemampuan mereka dalam membantu anak-anak mereka belajar. Dengan tingkat keyakinan tersebut maka akan berpengaruh secara signifikan terhadap kemampuan akademis anak-anak

\section{SIMPULAN}

Berdasarkan analisis yang peneliti lakukan dari artikel yang menjadi bahan rujukan, dapat peneliti ambil sebuah kesimpulan bahwasanya tingkat pendidikan orang tua memberikan pengaruh yang besar terhadap prestasi belajar seorang anak. Orang tua dengan tingkat pendidikan yang lebih tinggi juga memungkinkan untuk lebih percaya diri pada kemampuan mereka dalam membantu anak-anak mereka belajar. Dengan tingkat keyakinan tersebut maka akan berpengaruh secara signifikan terhadap kemampuan akademis anak-anak. Melalui tulisan ini agar dapat menjadi renungan dan bahan instropeksi bagi para orang tua, jangan hanya orang tua menuntut anak untuk bisa dan meraih prestasi belajar yang baik, akan tetapi para orang tua juga memiliki tanggung jawab untuk terus belajar, karena semakin tinggi tingkat pendidikan atau ilmu yang dimiliki oleh orang tua, akan mendorong prestasi belajar yang baik bagi seorang anak.

${ }^{19}$ Henry Eryanto,.... hlm. 51 


\section{DAFTAR PUSTAKA}

Ansor Sokhibul, 2017, Studi Meta Analisis Strategi Dan Pemanfaatan Jurnal Elektronik (E - Journals) Untuk Mahasiswa Lulusan Universitas Negeri Malang Dalam Upaya Publikasi Ilmiah Bereputasi Internasional, Record And Library Journal, Vol 3, No 1

Eryanto Henry, Darma Rika, 2013, Pengaruh Modal Budaya, Tingkat Pendidikan Orang Tua Dan Tingkat Pendapatan Orang Tua Terhadap Prestasi Akademik Pada Mahasiswa Fakultas Ekonomi Universitas Negeri Jakarta, Jurnal Pendidikan Ekonomi Dan Bisnis Vol.1 No. 1

Pratiwi Noor Komari, 2015, Pengaruh Tingkat Pendidikan, Perhatian Orang Tua, Dan Minat Belajar Siswa Terhadap Prestasi Belajar Bahasa Indonesia Siswa Smk Kesehatan Di Kota Tangerang, Jurnal Pujangga Volume 1, Nomor 2, Desember 2015. hlm.78

Reskia Sri dkk, 2014, Pengaruh Tingkat Pendidikan Orang Tua Terhadap Prestasi Belajar Siswa Di Sdn Inpres 1 Birobuli, Elementary School of Education EJournal, Media Publikasi Ilmiah Prodi PGSD Vol 2, Nomor 2

Saputri Maulida Anggraina, 2020, Penerapan Model Pembelajaran Problem Based Learning Untuk Meningkatkan Kemampuan Berfikir Kritis Siswa Kelas V Sekolah Dasar, Jurnal pendidikan dan konseling, Vol. 1 No. 2

Sugiyono, 2018, Metode Penelitian Kuantitatif, Kualitatif dan R\&D, Bandung: Alfabeta

Widiarto,2013, Penelitian ex post facto, Fakultas Teknik Universitas Negeri Yogyakarta 